\title{
Plukenetia huayllabambana Fruits: Analysis of Bioactive Compounds, Antibacterial Activity and Relative Action Mechanisms
}

\author{
Armel Jackson Seukep ${ }^{1,2,3,4} \mathbb{C}^{\text {, Minxia Fan }}{ }^{1,3,4}$, Satyajit Dey Sarker ${ }^{5}{ }^{\circledR}$, Victor Kuete ${ }^{6}$ \\ and Ming-Quan Guo ${ }^{1,3,4, *}$ \\ 1 CAS Key Laboratory of Plant Germplasm Enhancement and Specialty Agriculture, Wuhan Botanical Garden, \\ Chinese Academy of Sciences, Wuhan 437004, China; seukep.armel@ubuea.cm (A.J.S.); \\ fanminxia14@mails.ucas.ac.cn (M.F.) \\ 2 Department of Biomedical Sciences, Faculty of Health Sciences, University of Buea, P.O. Box 63, \\ Buea, Cameroon \\ 3 Sino-Africa Joint Research Center, Chinese Academy of Sciences, Wuhan 437004, China \\ 4 Innovation Academy for Drug Discovery and Development, Chinese Academy of Sciences, \\ Shanghai 201203, China \\ 5 Centre for Natural Products Discovery, School of Pharmacy and Biomolecular Sciences, Liverpool John \\ Moores University, Liverpool L3 3AF, UK; S.Sarker@ljmu.ac.uk \\ 6 Unit of Research in Microbiology and Antimicrobial Substances/Laboratory of Cancer Research, \\ Department of Biochemistry, Faculty of Science, University of Dschang, P.O. Box 67, Dschang, Cameroon; \\ victor.kuete@univ-dschang.org \\ * Correspondence: guomq@wbgcas.cn; Tel./Fax: +86-27-8770-0850
}

Received: 5 August 2020; Accepted: 25 August 2020; Published: 28 August 2020

\begin{abstract}
Plukenetia huayllabambana is an edible plant traditionally used to cure wounds and various infections. The present work assessed, for the first time, the antibacterial efficacy of solvent fractions from P. huayllabambana fruits. The crude methanol extract was obtained applying ultrasound-assisted extraction, followed by partitioning through successive depletion among solvents of increasing polarity to yield fractions (n-hexane, dichloromethane, ethyl acetate, and n-butanol). The minimal inhibitory concentration (MIC) was determined following antibacterial testing, using the broth microdilution technique against a panel of drug-resistant Gram-negative and Gram-positive bacteria. Possible modes of action of the most active fraction were also investigated. Gas chromatography-mass spectrometry (GC-MS) was used to identify phytocompounds that may account for the recorded activities. Methanol, n-hexane (PH-n-Hex), and ethyl acetate extracts inhibited 100\% of studied bacteria, with the recorded MIC ranging from $0.125-1 \mathrm{mg} / \mathrm{mL}$. PH-n-Hex appeared as the most active partition, exerting a bacteriostatic effect. $\mathrm{PH}-\mathrm{n}-\mathrm{Hex}$ probably acts by interfering with bacterial biofilm formation, proton pumps, and bacterial cell membrane integrity. The GC-MS analysis of $\mathrm{PH}-\mathrm{n}-\mathrm{Hex}$ led to the identification of 11 potentially bioactive components, including fatty acids, phytosterol, and diterpene alcohol as major ones. P. huayllabambana can be considered as a plant of pharmacological value - a source of potent anti-infective drug entities.
\end{abstract}

Keywords: Plukenetia huayllabambana; solvent fractions; antibacterial; modes of action; GC-MS

\section{Introduction}

Antimicrobial resistance (AMR) is a rising threat to global health [1]. The AMR crisis leads to prolonged hospital stays, inflated medical costs, and a higher rate of death [1,2]. It is estimated that more than 700,000 people die of resistant infections every year. If no active solution to the problem is found 
now, the estimate says millions of people will die due to AMR in the coming years [3]. The scarcity of new, less toxic antibiotic molecules with a novel mode of action that are less prone to drug resistance propels the development of alternative medicine. Plants have been used since ancient times for the prevention and/or treatment of several disorders. The acquaintance of the plant healing properties has been inherited over the centuries within and among human communities [4,5]. Medicinal plants have important antibiotic biochemistry to protect themselves against various infections and these properties can be transferred to humans [4]. Indeed, plants produced active secondary metabolites that account for the pharmacological properties including the treatment of infectious diseases [6]. The data generated from the anti-infective efficacy of several herbals medicine used in traditional medicine have been scientifically confirmed [5-13]. Numerous studies have aimed to characterize the chemical composition of antimicrobials from plants, and their modes of action, either separately or in combination with commonly used antibiotics [5]. Edible plants are of growing interest nowadays [12,14]. The scientific validation and creation of research data on the quality, safety, and efficacy of folk medicine have become a pressing issue. Such scientific knowledge can help create an evidence-based traditional medicine that is increasingly respected by other public health professionals. The presence of phytochemicals (nutraceuticals), in addition to nutrients, in dietary fruits, spices, condiments, and other vegetables, is considered of crucial nutritional importance in the prevention of chronic diseases, including bacterial infections [12].

Plant species belonging to the family Euphorbiaceae contain a high diversity of phytochemicals, including terpenoids, phenolic compounds, alkaloids, and fatty acids [15,16]. This variability of plant chemicals may account for the varied uses of the plants from this family as among others, anti-infective agents [15]. The studied plant-Plukenetia huayllabambana (R. W. Bussmann, C. Téllez \& A. Glenn) (Euphorbiaceae), also known as 'Giant Sacha Inchi' or 'Giant Inca Peanut', is a native plant to the tropical rain forest of the Amazon region of South America [17]. P. huayllabambana is closely related to another species of the same genus, namely Plukenetia volubilis, commonly known as 'Sacha Inchi' or 'Inca Peanut'. The two species differ in morphological and physicochemical properties. The morphological dissimilarity between P. volubilis and P. huayllabambana might also involve variance in the phytochemical composition. Indeed, Chirinos and collaborators [18] revealed pretty similarly fatty acid profiles for both species but P. huayllabambana presented a significantly higher content of alpha-linolenic acid than P. volubilis, while important contents of $\gamma$ - and $\delta$-tocopherol were evidenced in both oils. $\beta$-Sitosterol was the most important and representative phytosterol. In Cameroon, P. huayllabambana is used for alimentation and therapeutics. Seeds are edible (in a cooked or roasted form), while other parts of the plant are used traditionally to cure wounds and various infections. Most of the reported biological effects are related to seed-derived oils, while there are almost no studies on organic extracts. Sacha inchi oil-related products have been reported to exhibit anti-adherent activity against Staphylococcus aureus, skin tightening, anti-aging effects [19], and anti-inflammatory properties [20]. P. huayllabambana has been characterized as a rich source of fatty acids (saturated, mono- and polyunsaturated) comprising linolenic and linoleic acids as major ones. It also contains varied pharmacologically active compounds such as $\gamma$ - and $\delta$-tocopherol, phytosterol (high content of sitosterol), phenyl alcohols, and phenolic compounds including flavonoids, secoiridoids, and lignans $[18,21,22]$. In the present work, we evaluated the antibacterial efficacy of the crude methanolic extract and solvent fractions from $P$. huayllabambana fruits against five drug-resistant Gram-negative and Gram-positive bacteria, and the evaluation of the antibacterial modes of action. The gas chromatography coupled to mass spectrometry (GC-MS) analysis for bioactive components identification was performed on the n-hexane fraction. 


\section{Results and Discussion}

\subsection{GC-MS Profiling of Potential Bioactive Phytoconstituents}

The GC-MS analysis of PH-n-Hex led to the identification of 11 phytoconstituents (Figure 1, Table 1). Only compounds that showed the significance of similarity percentage $\geq 85 \%$ were considered. Above this value, there is a high probability to get a correct identification [23]. Major components identified were monounsaturated (oleic acid, octadeca-11-enoic acid, and methyl oleate,) and saturated (palmitic acid, methyl palmitate) fatty acids and beta-sitosterol. Other identified compounds with an area percentage $<2 \%$ included methyl linoleate, phytol, methyl stearate, hexahydrofarnesyl acetone, and diisobutyl phthalate. Oleic acid [24] was identified as the main component (46.55\%). Our results were consistent with previous findings, since some studies displayed similar phytochemicals constituents from P. huayllabambana, in particular, the fatty acid and phytosterol contents $[18,25]$. Indeed, the investigations carried out by Ramos-Escudero et al. [25] reported the presence of oleic acid, palmitic acid, and triterpene alcohol in P. huayllabambana. Chirinos et al. [18] previously identified $\beta$-sitosterol as the most important and representative phytosterol (as in most plants) found in P. huayllabambana. The chemical structures of the major phytoconstituents identified were shown in Figure 2.

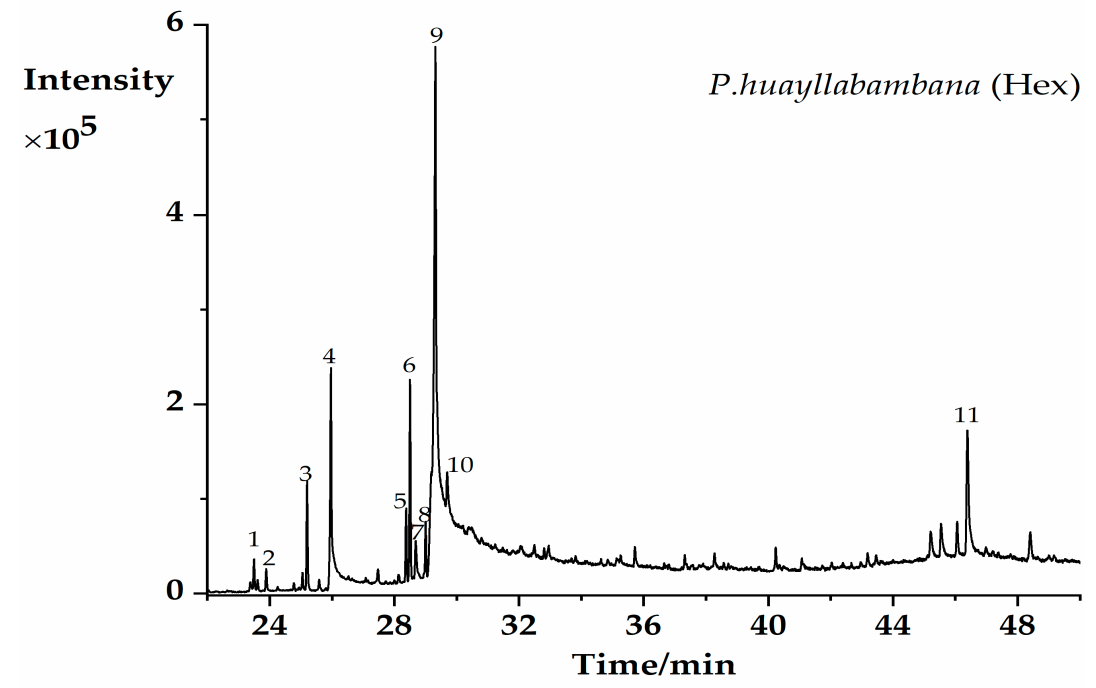

Figure 1. Gas chromatography-mass spectrometry (GC-MS) chromatogram of the P. huayllabambana n-hexane fraction. The peak numbers in this figure correspond to those used in Table 1.

Table 1. Identified components from the n-hexane fraction of $P$. huayllabambana by gas chromatographymass spectrometry (GC-MS) analysis.

\begin{tabular}{cccccc}
\hline PK & RT (min) & Chemical Formula & Compounds & Area $\%$ & Match \%** \\
\hline 1 & 23.503 & $\mathrm{C}_{18} \mathrm{H}_{36} \mathrm{O}$ & Hexahydrofarnesyl acetone & 0.9 & 90.2 \\
2 & 23.89 & $\mathrm{C}_{16} \mathrm{H}_{22} \mathrm{O}_{4}$ & Diisobutyl phthalate & 0.69 & 85.7 \\
3 & 25.198 & $\mathrm{C}_{17} \mathrm{H}_{34} \mathrm{O}_{2}$ & Methyl palmitate & 3.05 & 92.6 \\
4 & 25.967 & $\mathrm{C}_{16} \mathrm{H}_{32} \mathrm{O}_{2}$ & palmitic acid & 11.41 & 93.6 \\
5 & 28.375 & $\mathrm{C}_{19} \mathrm{H}_{34} \mathrm{O}_{2}$ & Methyl linoleate & 1.97 & 90.4 \\
6 & 28.507 & $\mathrm{C}_{19} \mathrm{H}_{36} \mathrm{O}_{2}$ & Methyl oleate & 5.36 & 92.4 \\
7 & 28.682 & $\mathrm{C}_{20} \mathrm{H}_{40} \mathrm{O}$ & Phytol & 1.96 & 89.5 \\
8 & 29.001 & $\mathrm{C}_{19} \mathrm{H}_{38} \mathrm{O}_{2}$ & Methyl stearate & 1.57 & 88.1 \\
9 & 29.314 & $\mathrm{C}_{18} \mathrm{H}_{34} \mathrm{O}_{2}$ & Oleic acid & 46.55 & 92.4 \\
10 & 29.695 & $\mathrm{C}_{18} \mathrm{H}_{34} \mathrm{O}_{2}$ & Octadeca-11-enoic acid & 7.79 & 87.4 \\
11 & 46.384 & $\mathrm{C}_{29} \mathrm{H}_{50} \mathrm{O}$ & beta-Sitosterol & 8.3 & 87.3 \\
\hline
\end{tabular}

PK: number of peaks identified. RT: retention time of the chromatogram (in minutes). ${ }^{* *}$ The significance of the similarity percentage was $\geq 85 \%$ [23]. 
<smiles>CCCCCCC=CCCCCCCCCCC(=O)O</smiles>

Octadeca-11-enoic acid<smiles>CCCCCCCCC=CCCCCCCCC(=O)O</smiles>

Oleic acid

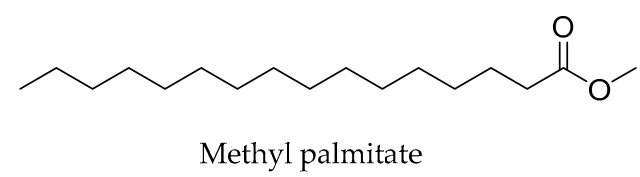<smiles>CCCCCCCCCCCCCCCC(=O)O</smiles>

Palmitic acid<smiles>CCCCCCCC/C=C/CCCCCCCC(=O)OC</smiles>

Methyl oleate<smiles>CCCCCCCCC(C)C1CCC2C3CC=C4CC(O)CCC4(C)C3CCC12C</smiles>

Figure 2. Chemical structures of identified major bioactive components from the n-hexane fraction of P. huayllabambana.

\subsection{Antibacterial Activity}

The upsurge of bacterial drug-resistant infections is a permanent public health concern. The resistance crisis urges the scientific community to seek for effective alternative therapeutic compounds with unusual modes of action [1]. This accounts for the rush for natural substances comprising medicinal plants. Indeed, medicinal plants produce structurally diverse secondary metabolites with a wide range of biological properties [26]. In the present study, we examined the antibacterial efficacy of the methanol extract $(\mathrm{PH}-\mathrm{MeOH})$ and subsequent partition fractions (n-hexane, dichloromethane, ethyl acetate, and n-butanol) from P. huayllabambana fruits. The recorded minimal inhibitory concentration (MIC) values are summarized in Table 2. Bacteria used in this work (Enterococcus faecalis, Staphylococcus aureus, Salmonella enterica, Klebsiella pneumoniae, and Enterobacter cloacae) are among those prioritized by the World Health Organization (WHO) in the research for novel antibacterial agents [1]. Preliminary investigations on the antibiotic resistance profile confirmed the resistance features of studied bacteria (data not shown). The studied Gram-positive and Gram-negative bacteria were found to be sensitive to the test solvent fractions. The latter were selectively active, with MIC values ranging from $0.125-1 \mathrm{mg} / \mathrm{mL}$ (Table 2). No bactericidal effects were recorded. The variation in activity recorded was probably linked with the type of extraction solvent. This may indicate that some antimicrobial active principles in P. huayllabambana fruits dissolve in varying degrees in solvents used. $\mathrm{PH}-\mathrm{MeOH}, \mathrm{PH}-\mathrm{n}-\mathrm{Hex}$, and the ethyl acetate fraction (PH-EA) displayed noteworthy inhibitory effects, preventing the growth of all tested bacterial strains $(100 \%)$.

Table 2. Minimal inhibitory concentrations (MICs) of the crude methanolic extract and subsequent partition fractions from P. huayllabambana fruits against studied bacterial strains.

\begin{tabular}{|c|c|c|c|c|c|c|c|c|}
\hline \multirow{2}{*}{\multicolumn{2}{|c|}{ Bacteria Strains }} & \multicolumn{5}{|c|}{$\begin{array}{l}\text { MICs }(\mathrm{mg} / \mathrm{mL}) \text { of Crude MeOH Extract and Fractions * of } \\
\qquad \text { P. huayllabambana }\end{array}$} & \multirow[t]{2}{*}{ METH } & \multirow[t]{2}{*}{ STR } \\
\hline & & $\mathrm{MeOH}$ & n-Hex & DCM & EA & n-BuOH & & \\
\hline \multirow{3}{*}{ Gram-negative } & S. enterica & 0.125 & 0.25 & 0.25 & 0.5 & 1 & 0.064 & 0.004 \\
\hline & E. cloacae & 1 & 1 & $>1$ & 1 & $>1$ & $>0.256$ & 0.064 \\
\hline & K. pneumoniae & 1 & 1 & $>1$ & 1 & $>1$ & $>0.256$ & $>0.256$ \\
\hline \multirow{2}{*}{ Gram-positive } & S. aureus & 0.5 & 0.5 & 1 & 1 & $>1$ & 0.125 & 0.004 \\
\hline & E. faecalis & 0.25 & 0.5 & 0.5 & 1 & $>1$ & 0.032 & 0.125 \\
\hline
\end{tabular}

* Each fraction tested in triplicate. MIC: minimal inhibitory concentration; MeOH: methanol, n-Hex: hexane, DCM: dichloromethane, EA: ethyl acetate, n-BuOH: n-Butanol. Positive controls: methicillin (METH) and streptomycin (STR). 
Except for the n-butanol fraction ( $\mathrm{PH}-\mathrm{n}-\mathrm{BuOH})$, other fractions showed potential strong activities (MIC $\leq 0.5 \mathrm{mg} / \mathrm{mL}$ ) against $S$. enterica. The antibacterial activity of plant extracts is considered very interesting (highly active) if MIC $<0.1 \mathrm{mg} / \mathrm{mL}$, active or moderately active if $0.1 \leq \mathrm{MIC} \leq 1 \mathrm{mg} / \mathrm{mL}$, and low if MIC $>1 \mathrm{mg} / \mathrm{mL}$ [27]. Therefore, no highly active extract was obtained from the present study. However, since recorded MICs varying from 0.125 to $1 \mathrm{mg} / \mathrm{mL}$, these suggested moderate activity against studied drug-resistant bacteria. The best activities were obtained with $\mathrm{PH}-\mathrm{MeOH}$ and PH-n-hexane against S. enterica, and the two Gram-positive bacteria E. faecalis and S. aureus. To the best of our knowledge, the antibacterial activity of $\mathrm{PH}-\mathrm{MeOH}$ and subsequent partition fractions from the fruits of P. huayllabambana (Euphorbiaceae) is being reported in this study for the first time. However, the antibacterial properties of many plants of the family Euphorbiaceae have previously been reported in the literature $[15,16,28]$. Few studies have documented the antimicrobial properties of plants from the genus Plukenetia. The present investigation, therefore, provides valuable information for the antibacterial activity of $P$. huayllabambana. The antibacterial activity of $P$. huayllabambana solvent fractions was probably due to the presence of naturally occurring bioactive components. The nature of the solvent of extraction, the amount of various chemical components in the extract, as well as the possible interactions between them, are some factors that can influence the activity. The differences in sensitivity recorded for the same extract with different bacteria strains could be explained by intrinsic differences in the chemical composition of the bacterial cell wall and/or in the genetically resistant elements, which may/not be transferable between strains such as plasmids or transposons [29]. Moreover, the differences recorded for the same bacterium and different fractions can be due to the qualitative and quantitative differences of antimicrobial active principles or by differences in the mechanisms of action of bioactive constituents [30]. Indeed, the active ingredients targeting the bacterial cell wall must find complementary receptors for their interaction that are appropriate for their action, while those acting inside the cell must be both able to cross the membrane and find target elements in the cell [14]. Among the five bacteria tested, Gram-negative bacteria (E. cloacae and K. pneumoniae) were found to most resist the effects of the test samples. These results were consistent with the common observations that Gram-negative bacteria are usually more resistant to botanicals than their counterpart Gram-positive ones. The resistance of Gram-negative bacteria towards antibacterial substances was owed to the presence of an outer membrane that takes part in the natural resistance by acting as an effective permeability barrier [31]. Common biological effects, comprising antibacterial activities, of $P$. huayllabambana were related to derived oils, commonly known as sacha inchi oils. For instance, sacha inchi oil-related products have been reported to exhibit anti-adherent activity against $S$. aureus [18], anti-aging effects [19], and anti-inflammatory properties [20]. The fact that PH-n-Hex was found to be the most effective fraction could probably be linked to its oil extraction capacity. Accordingly, in addition to its notable antibacterial effects, we have selected the lipophilic fraction (PH-n-Hex) to evaluate the possible mechanisms of action, as well as the identification of potentially bioactive components via GC-MS analysis.

The antimicrobial activities of the major compounds identified were widely documented. The possibility of the therapeutic use of fatty acids (both saturated and unsaturated) as antimicrobial agents is worthy of note [32], and the main ones identified in the present study could explain the antibacterial potential exerted by PH-n-Hex. Octadeca-11-enoic acid, an omega-7 fatty acid, is well known for its antibacterial activity [33]. Previous investigations also reported the antimicrobial activity of linoleic acid (and derivatives) and oleic acid against Gram-positive bacteria [34]. Likewise, palmitic acid, a long-chain saturated fatty acid, has been reported to exert notable antimicrobial activities against oral pathogens (bacteria and fungi) [35]. Furthermore, Sharma [36] underscored the antimicrobial activities of plant sterols including the one identified in the present study (beta-sitosterol). In addition, Sen and co-workers [37] have reported significant antimicrobial activities of beta-sitosterol against Gram-negative and Gram-positive bacteria including S. aureus and K. pneumoniae, some of the bacteria species used in this work. A diterpene alcohol phytol identified has been also reported to act as an antimicrobial agent [38]. The presence of these compounds in P. huayllabambana makes 
it a plant of pharmaceutical value. The identified compounds could act alone, or in interactions with other constituents of the mixture. The present work provided evidence of the traditional use of $P$. huayllabambana as an anti-infective plant. Most of the bacteria species examined in the present study are implicated in gastrointestinal troubles. Therefore, various solvent extracts from P. huayllabambana fruits, particularly PH-n-Hex, can be considered as promising candidates in the control of gastrointestinal diseases.

\subsection{Antibacterial Action Mechanisms}

\subsubsection{Antimicrobial Efficacy Testing}

Due to their chemical and structural diversity, plant-derived components act on different targets in bacteria cell structure including membrane, cell wall, and/or on molecular targets (ions or protons, proteins, DNA/RNA) by several mechanisms of action [14]. The antibacterial modes of action of $\mathrm{PH}-\mathrm{n}-\mathrm{Hex}$ were investigated against $\mathrm{S}$. enterica. That fraction was tested for antibacterial efficacy over time $(24 \mathrm{~h})$ at different concentrations (MIC, 2MIC, and 4MIC). At all tested concentrations (Figure 3), PH-n-Hex decreased bacterial counts over $24 \mathrm{~h}$ when compared to the starting inoculum. With increasing sample concentrations, a concentration-dependent trend towards greater bacterial killing was observed. The overall effect was bacteriostatic: PH-n-Hex inhibited the growth and reproduction of bacteria but did not kill them. This may point out the effect on bacterial metabolism. Like any bacteriostatic agent, a clinical application would require a collaboration of the bioactive agents with the host immune system to oust pathogenic bacteria from the body. However, high concentrations $(>4 \mathrm{MIC})$ could induce bactericidal effects.

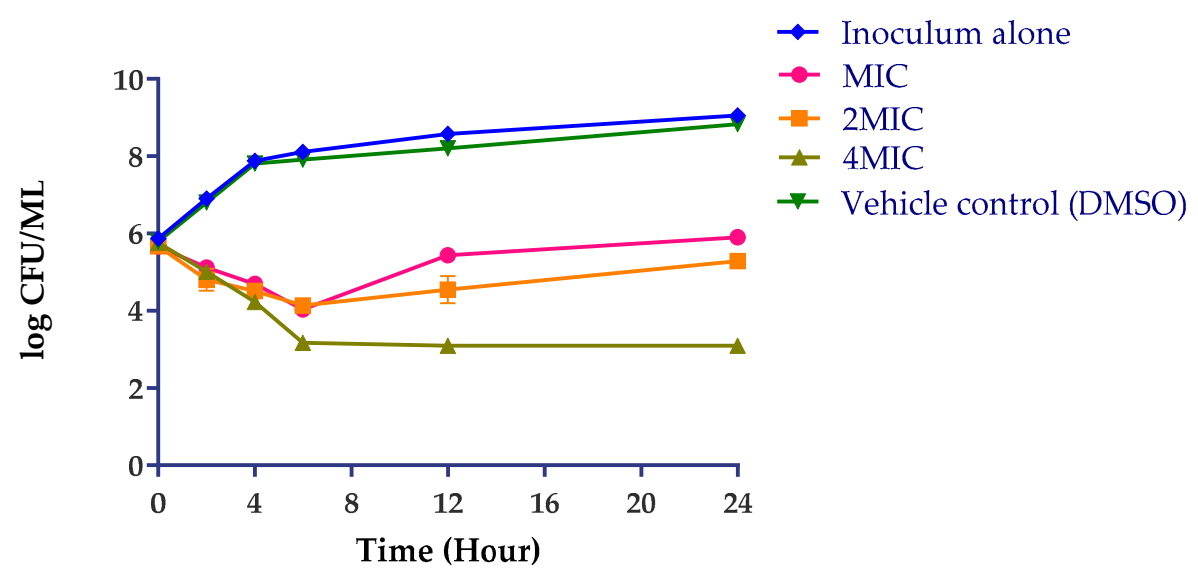

Figure 3. Antibacterial efficacy testing of P. huayllabambana n-hexane fraction on S. enterica. Time intervals: $0,2,4,6,12$, and $24 \mathrm{~h}$. Data are expressed as mean \pm SD $(p<0.05)$. MIC: minimum inhibitory concentration.

\subsubsection{Action on the Cell Membrane}

The action of the test extract (PH-n-Hex) on the S. enterica cell membrane was shown in Figure 4. The quantification of the release of UV-absorbing materials at OD260 was an indication of a serious and irreversible alteration of the cytoplasmic membrane. The release of intracellular content was an index of damage and loss of membrane integrity [39]. After treatment with PH-n-Hex at MIC and 4MIC, the OD increased up to 0.803 from 0.71 (Figure 4a). These observations implied that the test sample weakly damages the cytoplasmic membrane thereby leading to low leakage of S. enterica intracellular constituents. The percentage of crystal violet uptake significantly decreased after treatment with test material at MIC and 4MIC compared to untreated cells (Figure $4 \mathrm{~b}$ ). The difference in uptake of crystal violet from the bacterial cell wall after treatment compared to normal could be due to defective cell wall, as there were permeability changes [39]. The reduction in crystal violet uptake could probably be 
attributed to the enlargement of the treated cell, thereby changing the permeability and structure of the cell wall membrane layer compared to normal cells.
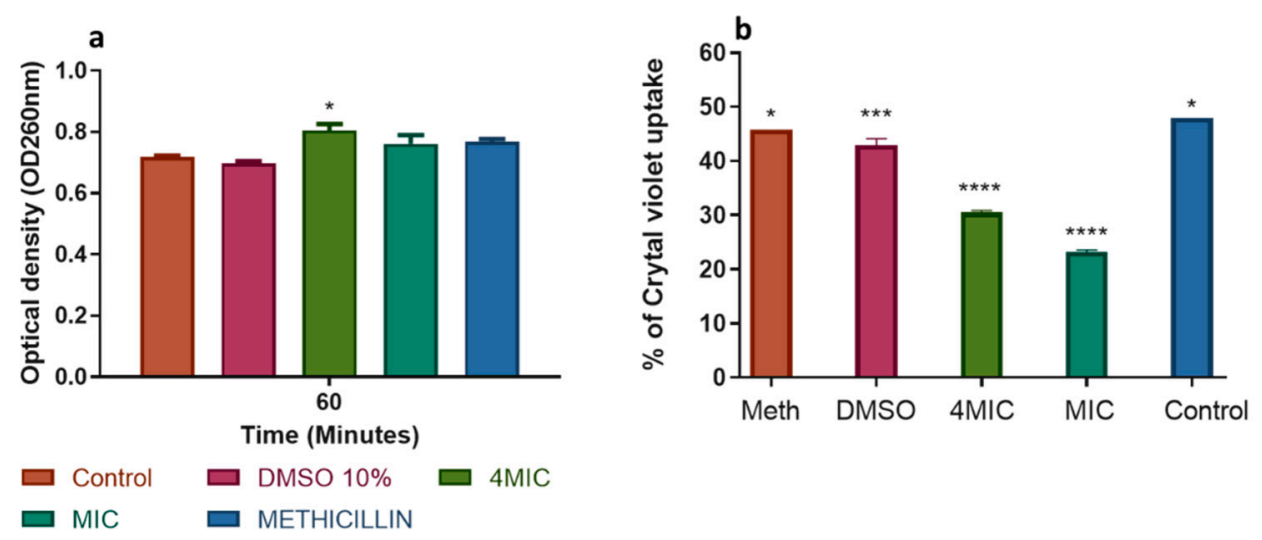

Figure 4. Modes of action of P. huayllabambana n-hexane fraction on S. enterica cell membrane. (a) Action on cell membrane integrity. Absorbance measurement of intracellular components (DNA, RNA) at OD260 $\mathrm{nm}$ after $1 \mathrm{~h}$ of incubation. (b) Action on membrane permeability. All data are expressed as mean \pm SD $(p<0.05)$. Meth: methicillin. MIC: minimum inhibitory concentration.

\subsubsection{Action on $\mathrm{H}^{+}$-ATPase-Mediated Proton Pumping}

The inhibition of S. enterica $\mathrm{H}^{+}$-ATPase-mediated proton pumping was noted after treatment with PH-n-Hex (Figure 5). Ion exchange systems in bacteria are coupled to the ATP energy synthesis used by the bacteria and any inhibition of their functioning (which results in a reduction in the acidification of the medium) could be detrimental to their survival. Cytoplasmic $\mathrm{pH}$ of bacteria cells is regulated by extrusion proton through the respiratory chain and $\mathrm{K}^{+}$influx at acid $\mathrm{pH}$, and cation/proton antiporter regulates the $\mathrm{pH}$ in alkaline states [40]. Every substance that disturbs the regulation of ATPase responsible for maintaining the homeostasis and osmotic stability of ions inside the cell is considered as a target of proton pumps. As shown in Figure 5, the test fraction induced inhibition of the glucose-induced acidification of the external medium by S. enterica in a timeand concentration-dependent manner. For instance, at 2MIC, the extract exerted a constant and total inhibition of $S$. enterica proton pumps, suggesting that the $\mathrm{H}^{+}$-ATPase of $S$. enterica is a potential cellular target of PH-n-Hex.

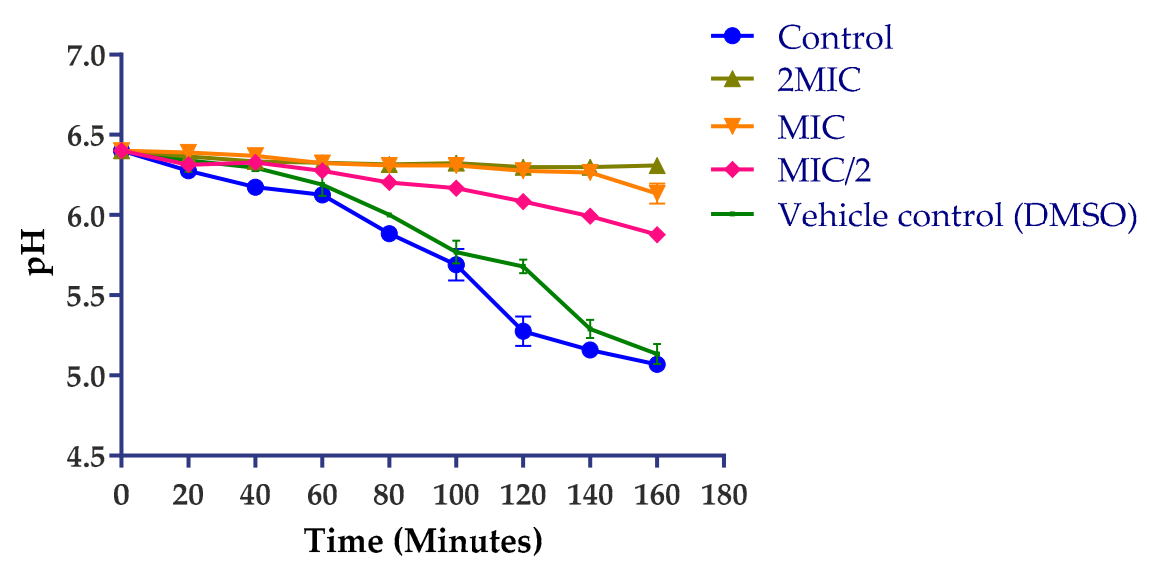

Figure 5. Action P. huayllabambana n-hexane fraction on S. enterica $\mathrm{H}^{+}$-ATPase-mediated proton pumping as a function of time. MIC: minimum inhibitory concentration. Data expressed as mean \pm SD $(p<0.05)$. 


\subsubsection{Action on Biofilm Formation}

PH-n-Hex depicted strong inhibition of S. enterica biofilm formation (up to 80\%) at inhibitory concentrations (MIC, $2 \mathrm{MIC}, 4 \mathrm{MIC}, 8 \mathrm{MIC}$ ) and between $50 \%$ and $70 \%$ at sub-inhibitory concentrations $(\mathrm{MIC} / 2, \mathrm{MIC} / 4, \mathrm{MIC} / 8, \mathrm{MIC} / 16)$ (Figure 6). No significant difference $(p<0.05)$ has been found between the values. The inhibition of the biofilm formation recorded at sub-inhibitory doses indicates the anti-biofilm activity of PH-n-Hex phytoconstituents. The molecular mechanism of plant extract on biofilm structure consists of targeting peptidoglycan synthesis and modulating the quorum sensing (QS), a whole gene involving in the regulation of biofilm formation [41]. Indeed, the QS regulates various functions in bacteria, including biofilm formation, antibiotic resistance, as well as the ability of bacteria to induce disease. The inhibition of biofilm formation by PH-n-Hex may be assigned to the presence of pharmacologically active phytoconstituents that act specifically on QS signaling pathways. Thereby, plant extract and its active compounds could inhibit signaling pathways of the QS that are involved in biofilm formation [42].

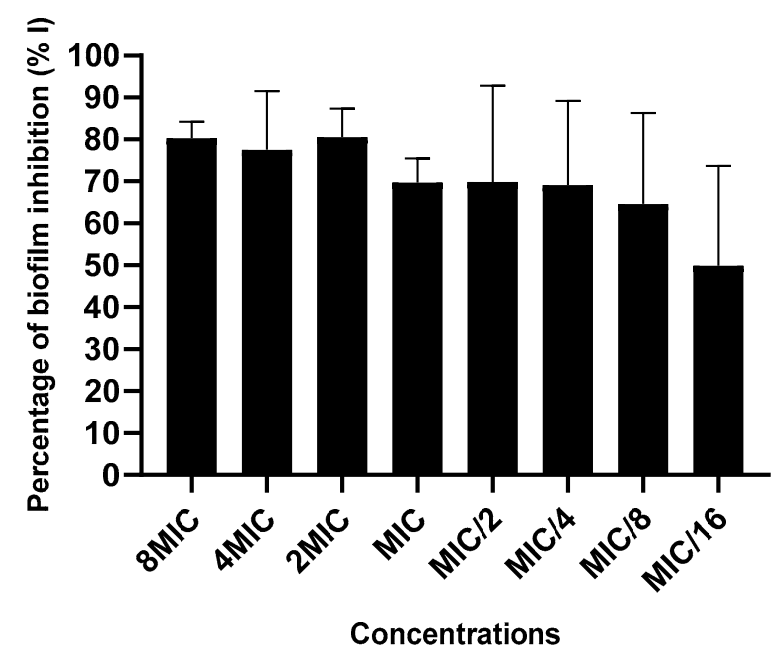

Figure 6. Action of P. huayllabambana n-hexane fraction on S. enterica biofilm formation. MIC: minimum inhibitory concentration. Data expressed as mean $\pm \operatorname{SD}(p<0.05)$.

\section{Materials and Methods}

\subsection{Chemicals and Reagents}

Bacterial culture media, trypticase soy agar (TSA) and trypticase soy broth (TSB), were purchased from Qingdao Hope Bio-Technology (Qingdao, China). Para-Iodonitrotetrazolium chloride (INT) 98\% was provided by Macklin (Shanghai, China). Dimethyl sulfoxide (DMSO $\geq 99.0 \%$ ) was obtained from Sinopharm Chemical Reagent (Shanghai, China). Streptomycin (purity $>98 \%$ ) (Abmole Biosciences, Houston, TX, USA) and methicillin (purity $>98 \%$, Cayman Chemical, Ann Arbor, MI, USA) were used as reference antibiotics for antibacterial testing.

\subsection{Plant Material}

Fruits of P. huayllabambana were collected in Bangangté, West Region, Cameroon (coordinates: $5.0880^{\circ} \mathrm{N}, 10.5184^{\circ} \mathrm{E}$ ) in July 2018. The authentication of the plant sample was done at the National Herbarium of Cameroon (HNC, Yaoundé, Cameroon) under a reference number (590718HNC). The fruits were cleaned out thoroughly and then cut into small pieces and air-dried, away from direct sunlight for 2 weeks. Afterwards, the air-dried plant material was ground into a fine homogenous powder. The powder obtained was packaged and kept at room temperature for future use. 


\subsection{Extraction Process of Plant Material}

The air-dried plant powder (100 g) was macerated into methanol (1:10 w/v) for $24 \mathrm{~h}$. After that, ultrasound-assisted extraction (KQ-500DE, Kunshan Ultrasonic Instrument Co., Ltd., Kunshan, China) was performed on the macerate for $30 \mathrm{~min}$, followed by filtration using Whatman filter paper grade 1 . The same procedure was repeated twice with the remaining residue. The overall filtrate was concentrated in a rotary evaporator at reducing pressure and temperature $\left(<45^{\circ} \mathrm{C}\right)$ to afford $7.68 \mathrm{~g}$ of crude methanolic $(\mathrm{MeOH})$ extract. Partitioning was prosecuted following the protocol previously described by Parsaee et al. [43]. Briefly, the resulting $\mathrm{MeOH}$ extract was first suspended in distilled water. Then, the aqueous solution obtained was partitioned by successive depletion among solvents of increasing polarity including n-hexane, dichloromethane, ethyl acetate, n-butanol, and finally water. Dried extracts were obtained after evaporation of residual solvents to yield residues of $1.8 \mathrm{~g}, 0.3 \mathrm{~g}$, $0.4 \mathrm{~g}, 0.5 \mathrm{~g}$, and $1.6 \mathrm{~g}$, respectively. $\mathrm{MeOH}$ extract and fractions were kept at $4{ }^{\circ} \mathrm{C}$ until further use.

\subsection{Gas Chromatography-Mass Spectrometry (GC-MS) Analysis}

The GC-MS analysis of the n-hexane fraction (PH-n-Hex) was performed using an Agilent 7890A GC-MS system, operating in an electron-impact mode of $70 \mathrm{eV}$. The GC system was equipped with a capillary column Agilent 19091S-433 $\left(325{ }^{\circ} \mathrm{C}, 30 \mathrm{~m}\right.$ long $\times 250 \mu \mathrm{m}$ id $\times 0.25 \mu \mathrm{m}$ film thickness) (Agilent Co., Santa Clara, CA, USA). The chromatographic conditions were as follows: sample preparation in hexane; injection volume $1 \mu \mathrm{L}$; split ratio 1:10; carrier gas helium flow rate $1.0 \mathrm{~mL} / \mathrm{min}$; column oven temperature programmed from 60 to $300{ }^{\circ} \mathrm{C}$, with a gradient of $5{ }^{\circ} \mathrm{C} / \mathrm{min}$; injector temperature $250{ }^{\circ} \mathrm{C}$. The identification of the chemical components was done by comparing their mass spectra and retention time with the data available in the National Institute of Standards and Technology (NIST) library (GC-MS System Nist. 11 lib.).

\subsection{Bacteria Strains}

Studied bacteria strains were from CCTCC (China Center for Type Culture Collection), CMCC (Center for Medical Culture Collection), and ATCC (American Type Culture Collection). These comprised two Gram-positive (Staphylococcus aureus CCTCC AB91093 and Enterococcus faecalis ATCC29212) and three Gram-negative bacterial strains (Salmonella enterica CCTCC AB94018, Enterobacter cloacae ATCC700323, and Klebsiella pneumoniae CMCC(B)46117). Trypticase soy agar (TSA) and trypticase soy broth (TSB) were used as culture media for antibacterial testing. TSA and TSB are non-selective, general-use culture media that supply enough nutritive elements, allowing for a broad variety of microorganisms to grow. Before any experiment, studied bacteria were subcultured (at $37^{\circ} \mathrm{C}$ for $18-24 \mathrm{~h}$ ) in TSA. TSB was used for microdilution and antibacterial mechanistic studies. Bacteria inoculum was initially prepared in sterile distilled water, the turbidity adjusted with a spectrophotometer to a McFarland standard of 0.5 , equivalent to $1.5 \times 10^{8} \mathrm{CFU} / \mathrm{mL}$.

\subsection{INT Colorimetric Assay for MIC and MBC Determination}

The antibacterial assay of $\mathrm{MeOH}$ extract and fractions were carried out in triplicate using a broth microdilution method for plant extracts in 96-wells microplates, using INT as the bacterial growth indicator [7-11,13,44]. Test extracts and reference antibiotics (Methicillin and Streptomycin) were dissolved in DMSO/TSB to obtain the working solution. The final concentration of DMSO in the assay was less than $2.5 \%$, a concentration innocuous to bacterial growth. The solution obtained was added to TSB, followed by a two-fold serial dilution in a 96-wells microplate. Subsequently, bacterial suspension initially prepared at the McFarland standard of $0.5\left(1.5 \times 10^{8} \mathrm{CFU} / \mathrm{mL}\right)$, as mentioned, was diluted in TSB, and $100 \mu \mathrm{L}$ of bacterial inoculum was seeded in the wells of plates containing test extracts. The final inoculum concentration was equivalent to $1.5 \times 10^{6} \mathrm{CFU} / \mathrm{mL}$. Afterwards, the plates were covered with a sterile plate sealer, then shaken to mix the contents of the wells using a plate shaker, followed by incubation at $37^{\circ} \mathrm{C}$ for $18 \mathrm{~h}$. Wells containing adequate TSB, $100 \mu \mathrm{L}$ of inoculum, 
and DMSO to a final concentration of $2.5 \%$ served as negative controls. The final concentration of the extracts varied from 0.008 to $1 \mathrm{mg} / \mathrm{mL}$, whereas that of antibiotics ranged from 0.002 to $0.25 \mathrm{mg} / \mathrm{mL}$. The minimal inhibitory concentration (MIC) of test samples was recorded after $18 \mathrm{~h}$ incubation at $37^{\circ} \mathrm{C}$, following the addition $(40 \mu \mathrm{L})$ of INT $0.02 \%(w / v)$ and another incubation at $37^{\circ} \mathrm{C}$ for $30 \mathrm{~min}$. The viable bacteria reduced the yellow dye to pink. Wells with test samples only (blank control) were used to ensure that the extracts were not producing color with INT. The minimal bactericidal concentration (MBC) was assessed by adding $50 \mu \mathrm{L}$ aliquots of the preparations, which did not show any growth after incubation during MIC testing, to $150 \mu \mathrm{L}$ of adequate broth. These preparations were incubated at $37^{\circ} \mathrm{C}$ for $48 \mathrm{~h}$. The MBC was considered as the lowest concentration of samples that prevented the color change of the medium after the addition of INT as abovementioned. The assays were performed in triplicate and repeated thrice.

\subsection{Action Mechanisms}

The n-hexane fraction (PH-n-Hex) appeared as the most active among partitions obtained, after the successive depletion of methanol extract. That fraction was used for mechanistic studies against the most sensitive bacteria strain (S. enterica).

\subsubsection{Antimicrobial Efficacy Testing}

The antimicrobial efficacy assay (time-kill kinetic assay) is applied to evaluate the activity of an antimicrobial agent against a bacterial strain and can establish the bactericidal or bacteriostatic activity of a compound over time. The assay was conducted based on the protocol earlier described by Appiah et al. [45], with slight modifications (final concentrations of test extract were equal to 4MIC, 2MIC, and MIC, whilst the time intervals for the kinetic study was as follows: 0, 2, 4, 6, 12, and $24 \mathrm{~h}$ ). The inoculum concentration was equivalent to $1.5 \times 10^{8} \mathrm{CFU} / \mathrm{mL}$.

\subsubsection{Action on Cell Membrane Integrity: Measurement of Intracellular Components (DNA/RNA)}

The release of UV-absorbing material concentrations was measured by UV-VIS spectrophotometer following the study conducted by Devi et al. [39]. Briefly, overnight cultures of S. enterica in TSB were adjusted to achieve the OD600 of 2.0. Cells were harvested by centrifugation ( $400 \times g, 15 \mathrm{~min})$, the supernatant was discarded, and the pellet was washed twice (using sterile deionized water) and then suspended in phosphate buffer saline (PBS, pH 7.4). Different concentrations of extract corresponding to MIC and 4MIC were added to the cell suspension. Methicillin was used as a positive control and cells without extract treatment were used as negative controls. The experiment was done in triplicate. All the samples were incubated at $37^{\circ} \mathrm{C}$ for $60 \mathrm{~min}$ under agitation. After treatment, the cell suspension was centrifuged $(13,400 \times g, 15 \mathrm{~min})$ and the OD260 value of the supernatant was taken as a percentage of the extracellular UV-absorbing materials released by cells. All the measurements were done in triplicates in MAPADA UV-VIS 1100 spectrophotometer (Shanghai Mapada Instruments Co., Ltd., Shanghai, China).

\subsubsection{Action on Membrane Permeability}

Crystal violet assay was applied to investigate the alteration in membrane permeability according to the protocol described by Devi et al. [39]. Briefly, suspensions of S. enterica were prepared in TSB. Cells were harvested after centrifugation $\left(4500 \times g, 5 \mathrm{~min}, 4^{\circ} \mathrm{C}\right)$ and were washed twice and suspended in PBS (pH 7.4). The bacteria cell suspension in buffer was treated with PH-n-Hex (at MIC and 4MIC) and methicillin (at MIC) followed by incubation $\left(37^{\circ} \mathrm{C}, 30 \mathrm{~min}\right)$. Likewise, control samples were prepared similarly without treatment. Another centrifugation $(9300 \times g, 5 \mathrm{~min})$ allowed the harvesting of cells, followed by the re-suspension in PBS containing $10 \mu \mathrm{g} / \mathrm{mL}$ of crystal violet. Afterward, the solution was incubated for $10 \mathrm{~min}$ at $37^{\circ} \mathrm{C}$, followed by centrifugation $(13,400 \times g, 15 \mathrm{~min})$, and the OD590 of the supernatant was measured using MAPADA UV-VIS 1100 spectrophotometer. The OD value of the crystal violet solution, which was originally used in the assay, was taken and it was 
considered as $100 \%$. The percentage of crystal violet (CV) uptake of tested samples was calculated using the following formula (Equation (1)):

$\%$ of $\mathrm{CV}$ uptake $=[\mathrm{OD}$ value of the sample/OD value of crystal violet solution $] \times 100$

\subsubsection{Action on $\mathrm{H}^{+}$-ATPase-Mediated Proton Pumping}

The ability of PH-n-Hex to inhibit the S. enterica $\mathrm{H}^{+}$-ATPase-mediated proton pumping was assessed by monitoring the acidification of the external medium through $\mathrm{pH}$ measurement using a pH-meter equipped with E-201-C combined electrode (PHSJ-3F pH Meter, INESA Scientific Instrument Co., Ltd., Shanghai, China), based on previously described protocol [28,46]. Briefly, $100 \mathrm{~mL}$ bacteria culture $(1: 100 \mathrm{v} / \mathrm{v})$ was grown in TSB culture medium for $18 \mathrm{~h}$ at $37^{\circ} \mathrm{C}$, followed by centrifugation $(3500 \times \mathrm{g}, 10 \mathrm{~min})$. The pellet was washed twice with distilled water and then with $50 \mathrm{mM} \mathrm{KCl}$ and re-suspended in $50 \mathrm{~mL}$ of $50 \mathrm{mM} \mathrm{KCl}$. The cell suspension $\left(1.5-2 \times 10^{8} \mathrm{CFU} / \mathrm{mL}\right)$ was incubated overnight $\left(18 \mathrm{~h}, 4^{\circ} \mathrm{C}\right)$ for glucose starvation and then centrifuged. In $4 \mathrm{~mL}$ of the reaction medium, $0.5 \mathrm{~mL}$ of PH-n-Hex corresponding to MIC/2, MIC, and 2MIC was added and the $\mathrm{pH}$ adjusted to 6.4. Upon $10 \mathrm{~min}$ pre-incubation under agitation at $37^{\circ} \mathrm{C}$, the acidification of the medium was initiated following the addition of $0.5 \mathrm{~mL}$ of glucose $20 \%(w / v)$. The $\mathrm{pH}$ measurement was recorded every $20 \mathrm{~min}$ for $160 \mathrm{~min}$. The experiment was conducted in the presence of DMSO (control) at a final concentration of $2.5 \%$, to measure the extent of acidification of the external medium in the absence of the plant extract. The experiment was performed in triplicate and repeated twice. The measured $\mathrm{pH}$ values were used to plot the $\mathrm{pH}$ evolution curve as a function of time $[\mathrm{pH}=\mathrm{f}(\mathrm{time})]$. Any inhibition of the acidification of the medium in the presence of the extract has been ascribed to an inhibitory effect of the $\mathrm{H}^{+}$-ATPase pumps.

\subsubsection{Action on Biofilm Formation}

Biofilm assay was assessed using crystal violet assay (96-well microtitre plate assay for biofilm quantification), as previously described $[47,48]$. The first phase of the assay was similar to that of MIC determination, mentioned above. The serial twofold dilution led to the concentration ranging from $1 / 16 \mathrm{MIC}$ to $8 \mathrm{MIC}$. However, the incubation time was $24 \mathrm{~h}$ at $37^{\circ} \mathrm{C}$. The next step consisted of gentle removal of each well content by tapping the plates. Subsequently, the wells were washed with $200 \mu \mathrm{L}$ sterile saline solution $(\mathrm{NaCl} 0.9 \%)$ to remove free-floating bacteria and then dried and fixed at $65^{\circ} \mathrm{C}$ for $1 \mathrm{~h}$. Biofilms formed by adherent cells in plates were stained with $0.8 \%(w / v)$ crystal violet followed by incubation at room temperature for $20 \mathrm{~min}$. Excess stains were rinsed off by thorough washing with deionized water and plates were fixed with $200 \mu \mathrm{L}$ of $30 \%(v / v)$ acetic acid. Blank control (TSB + extract), growth control (cells + TSB), and media control (only TSB) were included in the assay. Optical densities (OD) of stained adherent bacteria were measured at $590 \mathrm{~nm}$ using a microplate reader (Infinite M200 PRO, Tecan Group Ltd., Männedorf, Switzerland). All tests were performed in triplicate and repeated twice. The percentage of biofilm inhibition was calculated using the following formula (Equation (2)):

$$
\% \text { of biofilm inhibition }=[\mathrm{OD} \text { growth control }- \text { OD sample/OD growth control }] \times 100
$$

\subsection{Data Analysis}

Graphs were constructed using average data from triplicate readings of all experimental trials. Statistical significance was calculated using one-way ANOVA at $95 \%$ confidence interval followed by Dunnett's test and/or Tukey test for multiple means comparison. All data were analyzed using GraphPad Prism 8.0.1 Software (GraphPad Software Inc., San Diego, CA, USA). 


\section{Conclusions}

The anti-infective efficacy of the methanolic extract and subsequent partition fractions from P. huayllabambana fruits have been established as evident in the results obtained from the antibacterial assays. The GC-MS analysis of the n-hexane fraction led to the identification of 11 potentially bioactive components. These phytoconstituents (individually or in interactions with other components) probably act by interfering with bacterial biofilm formation, $\mathrm{H}^{+}$-ATPase-mediated proton pumping, and cell membrane integrity. The findings provided a baseline to consider the extracts from P. huayllabambana fruits, in particular the n-hexane fraction, in the control of drug-resistant infectious diseases. More investigations are required to isolate, characterize, and evaluate the biological properties of the identified bioactive components.

Author Contributions: Conceptualization, M.-Q.G.; Data curation, A.J.S., M.F., S.D.S., V.K. and M.-Q.G.; Formal analysis, M.-Q.G., A.J.S. and M.F.; Funding acquisition, M.-Q.G.; Investigation, A.J.S.; Methodology, A.J.S.; Project administration, M.-Q.G.; Resources, M.-Q.G.; Software, A.J.S., M.F., and M.-Q.G.; Supervision, M.-Q.G.; Validation/Visualization, A.J.S., M.F., S.D.S., V.K. and M.-Q.G.; Roles/Writing—original draft, A.J.S.; Writing-review \& editing, S.D.S.,V.K. and M.-Q.G. All authors have read and agreed to the published version of the manuscript.

Funding: The Chinese Academy of Sciences (CAS) President's International Fellowship Initiative (CAS-PIFI) projects [Grant No.2018PB0089 to AJS, and Grant No. 2019VBA0026 to SDS)] and the Major Project for Special Technology Innovation of Hubei Province [grant No. 2017AHB054] jointly supported this work.

Acknowledgments: We would like to thank Mbuntcha Gueaba Helene for helping with the collection of the plant samples. We also thank Guilin Chen for critically revising the manuscript before submission.

Conflicts of Interest: The authors declare no conflict of interest. The funders had no role in the design of the study; in the collection, analyses, or interpretation of data; in the writing of the manuscript, or in the decision to publish the results.

\section{References}

1. World Health Organization [WHO]. Prioritization of Pathogens to Guide Discovery, Research and Development of New Antibiotics for Drug-Resistant Bacterial Infections, Including Tuberculosis; World Health Organization: Geneva, Switzerland, 2017; WHO/EMP/IAU/2017.12.

2. Dadgostar, P. Antimicrobial Resistance: Implications and costs. Infect. Drug Resist. 2019, 12, 3903-3910. [CrossRef]

3. O'Neill, J. Tackling Drug-Resistant Infections Globally: Final Report and Recommendations. Review on Antimicrobial Resistance. 2016. Available online: http://amr-review.org/sites/default/files/160525_Final\% 20paper_with\%20cover.pdf. (accessed on 1 September 2019).

4. Kumar, M.; Yash, P.; Anand, V.K. An ethnobotanical study of medicinal plants used by the locals in Kishtwar, Jammu and Kashmir, India. Ethnobot. Leafl. 2009, 13, 1240-1256.

5. Silva, N.C.C.; Fernandes, J.A. Biological properties of medicinal plants: A review of their antimicrobial activity. J. Venom. Anim. Toxins Incl. Trop. Dis. 2010, 16, 402-413. [CrossRef]

6. Belyagoubi-Benhammou, N.; Belyagoubi, L.; Gismondi, A.; Di Marco, G.; Canini, A.; Bekkara, F.A. GC/MS analysis, and antioxidant and antimicrobial activities of alkaloids extracted by polar and apolar solvents from the stems of Anabasis articulata. Med. Chem. Res. 2019, 28, 754-767. [CrossRef]

7. Seukep, A.J.; Fankam, A.G.; Djeussi, D.E.; Voukeng, I.K.; Tankeo, S.B.; Noumedem, J.A.K.; Kuete, A.H.; Kuete, V. Antibacterial activities of the methanol extracts of seven Cameroonian dietary plants against bacteria expressing MDR phenotypes. Springerplus 2013, 2, 363. [CrossRef]

8. Seukep, A.J.; Ngadjui, B.T.; Kuete, V. Antibacterial activities of Fagara macrophylla, Canarium schweinfurthii, Myrianthus arboreus, Dischistocalyx grandifolius and Tragia benthamii against multi-drug resistant Gram-negative bacteria. Springerplus 2015, 4, 567. [CrossRef] [PubMed]

9. Seukep, A.J.; Sandjo, L.P.; Ngadjui, B.T.; Kuete, V. Antibacterial and antibiotic-resistance modifying activity of the extracts and compounds from Nauclea pobeguinii against Gram-negative multi-drug resistant phenotypes. BMC Complement. Altern Med. 2016, 16, 193. [CrossRef] [PubMed] 
10. Seukep, A.J.; Sandjo, L.P.; Ngadjui, B.T.; Kuete, V. Antibacterial activities of the methanol extracts and compounds from Uapaca togoensis against Gram-negative multi-drug resistant phenotypes. S. Afr. J. Bot. 2016, 103, 1-5. [CrossRef]

11. Manekeng, H.T.; Mbaveng, A.T.; Nguenang, G.S.; Seukep, J.A.; Wamba, E.N.B.; Nayim, P.; Yinkfu, N.R.; Fankam, A.G.; Kuete, V. Anti-staphylococcal and antibiotic-potentiating activities of seven Cameroonian edible plants against resistant phenotypes. Invest. Med. Chem. Pharmacol. 2018, 1, 7.

12. Kuete, V. Medicinal Spices and Vegetables from Africa: Therapeutic Potential against Metabolic, Inflammatory, Infectious and Systemic Diseases, 1st ed.; Elsevier: Amsterdam, The Netherlands, 2017; p. 697, ISBN 978-0-12-809286-6.

13. Seukep, A.J.; Zhang, Y.-L.; Xu, Y.-B.; Guo, M.-Q. In vitro antibacterial and antiproliferative potential of Echinops lanceolatus Mattf. (Asteraceae) and identification of potential bioactive compounds. Pharmaceuticals 2020, 13, 59. [CrossRef]

14. Seukep, A.J.; Kuete, V.; Nahar, L.; Sarker, S.D.; Guo, M. Plant-derived secondary metabolites as the main source of efflux pump inhibitors and methods for identification. J. Pharm. Anal., in press. [CrossRef]

15. Mwine, J.T.; van Damme, P. Why do Euphorbiaceae tick as medicinal plants? A review of Euphorbiaceae family and its medicinal features. J. Med. Plants Res. 2011, 5, 652-662.

16. Secco, R.D.S.; Cordeiro, I., II; de Senna-Vale, L.; de Sales, M.F.; de Lima, L.R.; Medeiros, D.; de Sá Haiad, B.; de Oliveira, A.S.; Caruzo, M.B.R.; Carneiro-Torres, D.; et al. An overview of recent taxonomic studies on Euphorbiaceae s.l. in Brazil. Rodriguesia 2012, 63, 227-242. [CrossRef]

17. Wang, S.; Zhub, F.; Kakudac, Y. Sacha inchi (Plukenetia volubilis L.): Nutritional composition, biological activity, and uses. Food Chem. 2018, 265, 316-328. [CrossRef]

18. Chirinos, R.; Zorrilla, D.; Aguilar-Galvez, A.; Pedreschi, R.; Campos, D. Impact of roasting on fatty acids, tocopherols, phytosterols, and phenolic compounds present in Plukenetia huayllabambana seed. J. Chem. 2016, 2016, 10. [CrossRef]

19. Gonzalez-Aspajo, G.; Belkhelfa, H.; Haddioui-Hbabi, L.; Bourdy, G.; Deharo, E. Sacha Inchi oil (Plukenetia volubilis L.) effect on adherence of Staphylococcus aureus to human skin explant and keratinocytes in vitro. J. Ethnopharmacol. 2015, 171, 330-334. [CrossRef]

20. Aguilar, J.L.; Dávila, P.S.R.; Lozada-Requena, I.A.; Cabello, M.A. Comparative evaluation of the anti-inflammatory effect of two varieties of "Sacha Inchi" (Plukenetia volubilis and Plukenetia huayllabambana) in mice. Front. Immunol. 2015. [CrossRef]

21. Nascimento, A.K.L.; Silveira, R.F.M.; Santos, N.D.; Fernandes, J.M.; Zucolotto, S.M.; Rocha, H.A.O.; Scortecci, K.C. Antioxidant and antiproliferative activities of leaf extracts from Plukenetia volubilis Linneo (Euphorbiaceae). Evid. Based Complement. Alternat. Med. 2013, 2013, 10. [CrossRef]

22. Muñoz, A.M.; Alvarado-Ruíz, C.; Castañeda, B.; Caparó, F.L.; Mendozac, E.B.; Lucero, L.C.; Cèspedes, E.M. Estúdio nutricional de Plukenetia huayllabambana sp. nov. (Text in spanish). Rev. Soc. Quim. Peru. 2013, 79, 47-56.

23. Stein, S.E. An integrated method for spectrum extraction and compound identification from GC/MS data. J. Am. Soc. Mass. Spectr. 1999, 10, 770-781. [CrossRef]

24. Schulz, S.; Peram, P.S.; Menke, M.; Hötling, S.; Röpke, R.; Melnik, K.; Poth, D.; Mann, F.; Henrichsen, S.; Dreyer, K. Mass spectrometry of aliphatic macrolides, important semiochemicals or pheromones. J. Nat. Prod. 2017, 80, 2572-2582. [CrossRef] [PubMed]

25. Ramos-Escudero, F.; Muñoz, A.M.; Ramos-Escudero, M.; Viñas-Ospino, A.; Morales, M.T.; Asuero, A.G. Characterization of commercial Sacha inchi oil according to its composition: Tocopherols, fatty acids, sterols, triterpene and aliphatic alcohols. J. Food Sci. Technol. 2019, 56, 4503-4515. [CrossRef] [PubMed]

26. Cowan, M.M. Plant products as antimicrobial agents. Clin. Microbiol. Rev. 1999, 12, 564-582. [CrossRef] [PubMed]

27. Silva, A.C.O.; Santana, E.F.; Saraiva, A.M.; Coutinho, F.N.; Castro, R.H.A.; Pisciottano, M.N.C.; Amorim, E.L.C.; Albuquerque, U.P. Which approach is more effective in the selection of plants with antimicrobial activity? Evid. Based Complement. Alternat. Med. 2013, 2013, 9. [CrossRef]

28. Kuete, V.; Poumale, H.M.P.; Guedem, A.N.; Shiono, Y.; Randrianasolo, R.; Ngadjui, B.T. Antimycobacterial, antibacterial and antifungal activities of the methanol extract and compounds from Thecacoris annobonae (Euphorbiaceae). S. Afr. J. Bot. 2010, 76, 536-542. [CrossRef] 
29. Nikaido, H. Prevention of drug access to bacterial targets: Permeability barriers and active efflux. Science 1994, 264, 382-388. [CrossRef]

30. Ono, T.; Kashimura, M.; Suzuki, K.; Oyauchi, R.; Miyachi, J.; Ikuta, H.; Kawauchi, H.; Akashi, T.; Asaka, T.; Morimoto, S. In vitro and in vivo antimicrobial activities of tricyclic ketolide Te-802 and its analogs. J. Antibiot. 2004, 57, 518-527. [CrossRef]

31. Dzoyem, J.P.; Guru, S.K.; Pieme, C.A.; Kuete, V.; Sharma, A.; Khan, I.A.; Saxena, A.K.; Vishwakarma, R.A. Cytotoxic and antimicrobial activity of selected Cameroonian edible plants. BMC Complement. Altern. Med. 2013, 13, 78. [CrossRef]

32. McGaw, L.J.; Jäger, A.K.; van Staden, J. Antibacterial effects of fatty acids and related compounds from plants. S. Afr. J. Bot. 2002, 68, 417-423. [CrossRef]

33. Semwal, P.; Painuli, S.; Badoni, H.; Bacheti, R.K. Screening of phytoconstituents and antibacterial activity of leaves and bark of Quercus leucotrichophora A. Camus from Uttarakhand Himalaya. Clin. Phytosci. 2018, 4, 30. [CrossRef]

34. Dilika, F.; Bremner, P.D.; Meyer, J.J. Antibacterial activity of linoleic and oleic acids isolated from Helichrysum pedunculatum: A plant used during circumcision rites. Fitoterapia 2000, 71, 450-452. [CrossRef]

35. Huang, C.B.; Altimova, Y.; Myers, T.M.; Ebersole, J.L. Short- and medium-chain fatty acids exhibit antimicrobial activity for oral microorganisms. Arch. Oral Biol. 2011, 56, 650-654. [CrossRef] [PubMed]

36. Sharma, R.K. Phytosterols: Wide-spectrum antibacterial agents. Bioor. Chem. 1993, 21, 49-60. [CrossRef]

37. Sen, A.; Dhavan, P.; Shukla, K.K.; Singh, S.; Tejovathi, G. Analysis of IR, NMR and antimicrobial activity of $\beta$-sitosterol isolated from Momordica charantia. Sci. Secure J. Biotech. 2012, 1, 9-13.

38. Pejin, B.; Savic, A.; Sokovic, M.; Glamoclija, J.; Ciric, A.; Nikolic, M.; Radotic, K.; Mojovic, M. Further in vitro evaluation of antiradical and antimicrobial activities of phytol. Nat. Prod. Res. 2014, 28, 372-376. [CrossRef] [PubMed]

39. Devi, K.P.; Nisha, S.A.; Sakthivel, R.; Pandian, S.K. Eugenol (an essential oil of clove) acts as an antibacterial agent against Salmonella typhi by disrupting the cellular membrane. J. Ethnopharmacol. 2010, 130, 107-115. [CrossRef]

40. Kobayashi, H. A proton-translocating ATPase regulates $\mathrm{pH}$ of the bacterial cytoplasm. J. Biol. Chem. 1985, $260,72-76$.

41. Lu, C.; Kirsch, B.; Zimmer, C.; de Jong, J.C.; Henn, C.; Maurer, C.K.; Müsken, M.; Häussler, S.; Steinbach, A.; Hartmann, R.W. Discovery of antagonists of PqsR, a key player in 2-alkyl-4-quinolone- dependent quorum sensing in Pseudomonas aeruginosa. Chem. Biol. 2012, 19, 381-390. [CrossRef]

42. Asfour, H.Z. Anti-quorum sensing natural compounds. J. Microsc. Ultrastruct. 2018, 6, 1-10. [CrossRef]

43. Parsaee, H.; Asilib, J.; Mousavic, S.H.; Soofi, H.; Emami, S.A.; Tayarani-Najarane, Z. Apoptosis induction of Salvia chorassanica root extract on human cervical cancer cell line. Iran. J. Pharm. Res. 2013, 12, 75-83.

44. Eloff, J.N. A sensitive and quick microplate method to determine the minimal inhibitory concentration of plant extracts for bacteria. Planta Med. 1998, 64, 711-713. [CrossRef]

45. Appiah, T.; Boakye, Y.D.; Agyare, C. Antimicrobial activities and time-kill kinetics of extracts of selected Ghanaian mushrooms. Evid. Based Complement. Alternat. Med. 2017, 2017. [CrossRef] [PubMed]

46. Manavathu, E.K.; Dimmock, J.R.; Vashishtha, S.C.; Chandrasekar, P.H. Inhibition of $\mathrm{H}^{+}$-ATPase-mediated proton pumping in Cryptococcus neoformans by a novel conjugated styryl keton. J. Antimicrob. Chemother. 2001, 47, 491-494. [CrossRef] [PubMed]

47. O'Toole, G.A.; Kolter, R. Initiation of biofilm formation in Pseudomonas fluorescens WCS365 proceeds via multiple, convergent signaling pathways: A genetic analysis. Mol. Microbiol. 1998, 28, 449-461. [CrossRef] [PubMed]

48. Etame, R.E.; Mouokeu, R.S.; Pouaha, C.C.L.; Voukeng, K.I.; Tchientcheu, R.; Assam, A.J.P.; Poundeu, M.F.S.; Tchinda, T.A.; Etoa, F.X.; Kuiate, J.R.; et al. Effect of fractioning on antibacterial activity of Enantia chlorantha Oliver (Annonaceae) methanol extract and mode of action. Evid. Based Complement. Alternat. Med. 2018, 2018, 13. [CrossRef]

(C) 2020 by the authors. Licensee MDPI, Basel, Switzerland. This article is an open access article distributed under the terms and conditions of the Creative Commons Attribution (CC BY) license (http://creativecommons.org/licenses/by/4.0/). 